\title{
Alternative to Water Based Fabric Cleaner in Textile and Detergent Processes
}

\author{
Arpan Jain \\ Biosystems Engineering Program, Department of Environmental Engineering and Earth Sciences, Clemson University, \\ Clemson, SC, USA \\ Correspondence should be addressed to Arpan Jain; arpanjain0211@gmail.com
}

Received 28 July 2016; Accepted 14 December 2016; Published 31 January 2017

Academic Editor: Satoshi Horikoshi

Copyright (C) 2017 Arpan Jain. This is an open access article distributed under the Creative Commons Attribution License, which permits unrestricted use, distribution, and reproduction in any medium, provided the original work is properly cited.

\begin{abstract}
Three different detergent formulations, (1) ethyl-hydro-oxides (EHOs, using ethanol $+\mathrm{H}_{2} \mathrm{O}_{2}+\mathrm{KOH}+$ water, without pH adjustment, at $60^{\circ} \mathrm{C}$ for $1 \mathrm{~h}$ ), (2) modified EHOs (using ethanol $+\mathrm{H}_{2} \mathrm{O}_{2}+\mathrm{KOH}+$ water, with $\mathrm{pH}$ adjustment, at $40^{\circ} \mathrm{C}$ for $1 \mathrm{~h}$ ), and (3) water based detergent (WBD, using commercial detergent $\mathrm{T}+$ water, at $40^{\circ} \mathrm{C}$ for $1 \mathrm{~h}$ ), were analyzed for cleaning of dried biodiesel soaked cotton cloth (DBSCC) samples. The effects of detergent formulations were analyzed based on cloth sample weights (residual and intact) and visual (through photographic images) examinations. With EHOs formulations, the increasing concentration of $\mathrm{KOH}$ and $\mathrm{H}_{2} \mathrm{O}_{2}$ had a significant effect on increasing both brightness and residual content of DBSCC samples. On the contrary, the controlled $\mathrm{pH}$ environments (as with modified EHOs formulations) had a significant effect in decreasing residual content and increasing brightness of DBSCC samples. The implications of EHOs formulations (with and without modification) are discussed with respect to current water based textile and detergent industries practices.
\end{abstract}

\section{Introduction}

Textile and detergent industries are necessary to fulfill a hygienic environment within a society. Textile industry produces cotton, wool, and synthetic fiber based fabrics. Among all these fabrics, cotton based fabrics are the most popular due to a wide consumer recognition (because of the high comfort level and the ability to absorb moisture) and textile medical importance [1]. In textile industry, production of cotton based fabric requires tremendous amount of water $[2,3]$. The conversion of yarn (after weaving and spinning operations) into the printed fabric requires the following different unit operations in a sequential order.

(1) Desizing: Cellulase enzymes are used to reduce the size of cotton fibers.

(2) Scouring: Alkaline or soap solutions are used to remove the extractive contents (wax or noncellulosic components) of cotton.

(3) Bleaching: This process is performed at $80^{\circ}-110^{\circ} \mathrm{C}$ using $10-30 \mathrm{~g} \mathrm{H}_{2} \mathrm{O}_{2}$ per $\mathrm{Kg}$ of fabric to increase the whiteness $[4,5]$. The alkaline condition (with $\mathrm{pH}<$
10.8) with $\mathrm{H}_{2} \mathrm{O}_{2}$ has been reported in the optimal bleaching [5].

(4) Mercerization: This process is performed using 110 $190 \mathrm{~g} \mathrm{NaOH}$ per $\mathrm{Kg}$ of fabric at $20^{\circ}-25^{\circ} \mathrm{C}$ [6]. The mercerization process converts native cotton (cellulose I) to mercerized cotton (cellulose II) [7]. The conversion of cellulose I to cellulose II increases both brightness and tensile strength of the fabric $[6,8]$. In addition, cellulose II provides a stable state for the dye adsorption [9]. Usually, water and acid wash (sulfuric acid) are employed for $\mathrm{pH}$ neutralization of the mercerized cotton fibers.

(5) Dyeing: This process operates at $\mathrm{pH}$ range of 4-12 using cationic and anionic dyes [8].

Approximately 42,000-123,000 liters of water per ton of finished cotton fabric (up to mercerization) is required [3].

On the other hand, detergent industry produces a wide range of consumer products such as bleaching, disinfectant, and laundry detergents for domestic and industrial applications [10]. Detergent industry utilizes chemical and biological methods for the production of detergent's ingredients [10-12]. 
Chemical methods involve the use of chemically synthesized hydrogen peroxide, phosphorus, caustic soda, hydrochloric acid, and peracetic acid. The selection of chemicals depends on the strength of a detergent formulation $[10,13]$. In the biological method, different microorganisms (fungus, bacteria, and yeast) are employed for the production of protein degrading (protease) and lipid degrading (lipase) enzymes [10-12]. Water based laundry detergent formulation comprises surfactant, builders, bleaches, antimicrobial agents, fabric softeners, fragrances, optical brighteners, preservative, hydrotropes (to prevent gel formation or separation), processing aids, and foam regulators (to reduce foam formation) [10]. Most of the commercial laundry detergent formulations are conditioned at $\mathrm{pH}$ of $8-11$ and at a temperature of $25^{\circ}-60^{\circ} \mathrm{C}$ [10]. The main goals of $\mathrm{pH}$ and temperature are to achieve optimal washing with chemical solvent properties and to decrease a surface tension of the solvent. A reduction in the surface tension of solvent is effective in accessing the inner matrix of fabric. In general, dirt is comprised of oil, grease, protein, carbohydrates, and soil. A dirt removal mechanism from the fabric involves the development of anionic species in the solvent that repels from cellulosic hydroxyl groups (in cotton based fabric) due to similar negative charges. The generated repulsion decreases the strength of attached dirt on the surface of the fabric and is released into the solvent. The released dirt is encapsulated by polymers (cellulose acetate) in the detergent formulation and is prevented from redeposition on the surface of the fabric. An alternative to water based fabric cleaner, such as perchloroethylene (also known as perc), is undesirable at a large scale application, due to its high energy requirement (during the recycling of solvent, boiling point $=121^{\circ} \mathrm{C}$ ), carcinogenic nature, and direct impact on the environment (i.e., chlorofluorocarbons based products). The discharge of pollutants through textile industry and detergent based products into water stream has affected the sustainability of the environment [14-17] and endangered or genetically mutated the natural flora $[18,19]$. Both textile and detergent industries are important commodities of society. It is important to eliminate the generated pollutants at the end of these processes. Furthermore, it is important to find alternative to water based processes (in textile and detergent) in water-limited regions (such as drought and dessert lands) to maintain a hygienic environment and to develop these industries. The use of organic solvent (using ethanol) in alkaline medium (using potassium hydroxide at 25-50 $\mathrm{g} \mathrm{L}^{-1}$ ) with oxidizing agent (using hydrogen peroxide at $25-50 \mathrm{~g} \mathrm{~L}^{-1}$ ) has been reported, known as ethyl-hydrooxides (EHOs) process, in the complete recycling of solvent mixture with the production of valuable bioproducts (such as pulp, enzyme hydrolyzate, therapeutic juice, and anticancer drug) and the development of integrated desalination process in the desert/drought regions of the world using structurally different lignocellulosic feedstocks [20, 21]. However, the application of EHOs process has not been reported in the development of textile and detergent processes.

The objective of the present research was to evaluate the effects of EHOs based detergent formulations on fabric cleaning by examining solvent polarity (by varying solvent composition of alkaline hydroxide, hydrogen peroxide, and ethanol) at different temperatures and $\mathrm{pH}$ values for both dirt removal and increasing the brightness of fabric. The implications of findings are discussed with a process integration and development including waste generation, salt formation, and thereafter regeneration of solvent stream, in textile and detergent processes.

\section{Materials and Methods}

2.1. Material and Detergent Formulations. DBSCC samples were obtained from a biodiesel lab facility at Biosystems Research Complex, Room 111, Clemson University, Clemson, SC. The physiochemical properties of different chemical reactants in EHOs detergent formulations (with possible replacement of a chemical reactant) are shown in Table 1 . The physiochemical properties of EHOs detergent formulations are discussed in Results and Discussion. The effects of different solvent detergent formulations were examined on the DBSCC samples as shown in Table 2. In $250 \mathrm{~mL}$ and $500 \mathrm{~mL}$ media bottles, DBSCC samples were added with $100 \mathrm{~mL}$ of different detergent formulations (Table 2). All samples were incubated in shake flask incubator at $40^{\circ}-60^{\circ} \mathrm{C}$ [10], with continuous agitation at 200 revolutions per minute for $1 \mathrm{~h} \mathrm{[12].} \mathrm{After} \mathrm{time} \mathrm{incubation,} \mathrm{the} \mathrm{final} \mathrm{pH}$ values of the solvents were measured. The detergent washed cloth samples were retained using $0.15-0.18 \mathrm{~mm}$ sieve size and were water washed with hands under a running tap water $\left(\right.$ at $\left.34^{\circ} \mathrm{C}\right)$ for 2 3 minutes. The intact part and residual of cloth samples were dried at $50^{\circ} \mathrm{C}$ for $12 \mathrm{~h}$ before analysis.

2.2. Analytical Methods. Both sample weights and visual analyses (through photographs) of DBSCC were performed before and after the washing process. The oven-dried washed cloth samples were examined using the following relationships:

$$
\begin{aligned}
& \text { Intact cloth (IC) content }(\%) \\
& \qquad=\frac{\text { Final weight of intact sample }(\mathrm{g})}{\text { Initial weight of sample }(\mathrm{g})} \times 100 \%
\end{aligned}
$$

Residual cloth (RC) content (\%)

$$
=\frac{\text { Weight of generated residues }(\mathrm{g})}{\text { Initial weight of sample }(\mathrm{g})} \times 100 \%
$$

Total retained cloth (TRC) content (\%)

$$
=\mathrm{IC} \text { content }(\%)+\mathrm{RC} \text { content }(\%) \text {. }
$$

2.3. Results Analysis. Different detergent formulations (EHOs, modified EHOs, and WBD) were analyzed with respect to controls (water and ethanol) to determine the effect on DBSCC samples. These comparisons were made based on IC, RC, and TRC contents of washed samples as responses. Images of DBSCC samples before and after washing were taken using Cannon PowerShot SD870 IS camera. The images of different detergent washed samples 
TABLE 1: Physicochemical properties of different chemical reactants in EHOs detergent formulations [22-24].

\begin{tabular}{|c|c|c|c|c|c|c|c|c|}
\hline $\mathrm{CR}(\mathrm{MF})$ & Two-dimensional structure & $\mathrm{MW}\left(\mathrm{g} \mathrm{mol}^{-1}\right)$ & $\mathrm{MP}\left({ }^{\circ} \mathrm{C}\right)$ & $\mathrm{BP}\left({ }^{\circ} \mathrm{C}\right)$ & $\mathrm{RB}$ & HD & $\mathrm{HA}$ & $\mathrm{pKa}^{*}$ \\
\hline Potassium hydroxide $(\mathrm{KOH})$ & & 56.1 & 380 & 1327 & 0 & 1 & 1 & 16 \\
\hline Ethanol $\left(\mathrm{C}_{2} \mathrm{H}_{6} \mathrm{O}\right)$ & & 46.1 & -114.1 & 78.3 & 0 & 1 & 1 & 15.5 \\
\hline Sodium hydroxide $(\mathrm{NaOH})^{\#}$ & $\mathrm{Na}^{+}$ & 40.0 & 323 & 1388 & 0 & 1 & 1 & 14.8 \\
\hline Water $\left(\mathrm{H}_{2} \mathrm{O}\right)$ & & 18.0 & 0 & 100 & 0 & 1 & 1 & 14 \\
\hline Hydrogen peroxide $\left(\mathrm{H}_{2} \mathrm{O}_{2}\right)$ & & 34.0 & -0.43 & 152 & 0 & 2 & 2 & 11.6 \\
\hline Citric acid $\left(\mathrm{C}_{6} \mathrm{H}_{8} \mathrm{O}_{7}\right)$ & & 192.1 & 153 & - & 5 & 4 & 7 & $\begin{aligned} \mathrm{pKa}_{1} & =3.1 \\
\mathrm{pKa}_{2} & =4.8 \\
\mathrm{pKa}_{3} & =6.4\end{aligned}$ \\
\hline
\end{tabular}

Note:

${ }^{\#} \mathrm{NaOH}$ represents the possible replacement of $\mathrm{KOH}$ in $\mathrm{EHOs}$ detergent formulations.

${ }^{*}$ pKa values are listed using water solvent at $25^{\circ} \mathrm{C}$.

CR: chemical reagent; MF: molecular formula; MW: molecular weight; MP: melting point; BP: boiling point; RB: rotatable bond count; HD: hydrogen bond donor count; HA: hydrogen bond acceptor count.

TABLE 2: Detergent formulations.

\begin{tabular}{|c|c|c|}
\hline Exp. \# & Initial sample weight $[\mathrm{g}]$ & Detergent formulations \\
\hline \multicolumn{3}{|c|}{ (1) EHOs (at $60^{\circ} \mathrm{C}$, without $p H$ adjustment) } \\
\hline $\mathrm{O} 1$ & 3.01 & $1 \mathrm{~g} \mathrm{KOH}+1.13 \mathrm{~g} \mathrm{H}_{2} \mathrm{O}_{2}+1.86 \mathrm{~g}$ water $+75.8 \mathrm{~g}$ ethanol \\
\hline $\mathrm{O} 2$ & 3.14 & $2 \mathrm{~g} \mathrm{KOH}+2.26 \mathrm{~g} \mathrm{H}_{2} \mathrm{O}_{2}+3.71 \mathrm{~g}$ water $+72.8 \mathrm{~g}$ ethanol \\
\hline $\mathrm{O} 3$ & 2.92 & $3 \mathrm{~g} \mathrm{KOH}+3.39 \mathrm{~g} \mathrm{H}_{2} \mathrm{O}_{2}+5.57 \mathrm{~g}$ water $+69.8 \mathrm{~g}$ ethanol \\
\hline $\mathrm{O} 4$ & 3.26 & $4 \mathrm{~g} \mathrm{KOH}+4.52 \mathrm{~g} \mathrm{H}_{2} \mathrm{O}_{2}+7.43 \mathrm{~g}$ water $+66.7 \mathrm{~g}$ ethanol \\
\hline O5 & 3.27 & $5 \mathrm{~g} \mathrm{KOH}+5.65 \mathrm{~g} \mathrm{H}_{2} \mathrm{O}_{2}+9.29 \mathrm{~g}$ water $+63.7 \mathrm{~g}$ ethanol \\
\hline O6 & 2.87 & $78.9 \mathrm{~g}$ ethanol (control) \\
\hline O7 & 2.96 & $100 \mathrm{~g}$ water (control) \\
\hline \multicolumn{3}{|c|}{ (2) Modified EHOs (at $40^{\circ} \mathrm{C}$, with $\mathrm{pH}$ adjustment) } \\
\hline $\mathrm{T} 1$ & 2.99 & $0.06 \mathrm{~g} \mathrm{KOH}+1.13 \mathrm{~g} \mathrm{H}_{2} \mathrm{O}_{2}+2.80 \mathrm{~g}$ water $+75.8 \mathrm{~g}$ ethanol \\
\hline $\mathrm{T} 2$ & 2.32 & $0.11 \mathrm{~g} \mathrm{KOH}+2.26 \mathrm{~g} \mathrm{H}_{2} \mathrm{O}_{2}+5.60 \mathrm{~g}$ water $+72.8 \mathrm{~g}$ ethanol \\
\hline $\mathrm{T} 3$ & 2.55 & $0.17 \mathrm{~g} \mathrm{KOH}+3.39 \mathrm{~g} \mathrm{H}_{2} \mathrm{O}_{2}+8.40 \mathrm{~g}$ water $+69.8 \mathrm{~g}$ ethanol \\
\hline $\mathrm{T} 4$ & 2.26 & $0.22 \mathrm{~g} \mathrm{KOH}+4.52 \mathrm{~g} \mathrm{H}_{2} \mathrm{O}_{2}+11.21 \mathrm{~g}$ water $+66.7 \mathrm{~g}$ ethanol \\
\hline T5 & 2.27 & $0.28 \mathrm{~g} \mathrm{KOH}+5.65 \mathrm{~g} \mathrm{H}_{2} \mathrm{O}_{2}+14.01 \mathrm{~g}$ water $+63.7 \mathrm{~g}$ ethanol \\
\hline T6 & 2.13 & $78.9 \mathrm{~g}$ ethanol (control) \\
\hline \multicolumn{3}{|c|}{ (3) $W B D$ (at $40^{\circ} \mathrm{C}$, commercial detergent) } \\
\hline D1 & 2.29 & $2 \mathrm{~g}$ T detergent $+98 \mathrm{~g}$ water \\
\hline D2 & 2.83 & $4 \mathrm{~g}$ T detergent $+96 \mathrm{~g}$ water \\
\hline D3 & 2.99 & $6 \mathrm{~g}$ T detergent $+94 \mathrm{~g}$ water \\
\hline D4 & 2.81 & $8 \mathrm{~g} \mathrm{~T}$ detergent $+92 \mathrm{~g}$ water \\
\hline D5 & 2.58 & $10 \mathrm{~g}$ T detergent $+90 \mathrm{~g}$ water \\
\hline D6 & 2.86 & $100 \mathrm{~g}$ water (control) \\
\hline
\end{tabular}

Note:

Total volume of detergent formulation $=100 \mathrm{~mL}$.

Weight of added $\mathrm{H}_{2} \mathrm{O}_{2}$ was calculated from stock solution of $350 \mathrm{~g} \mathrm{~L}^{-1} \mathrm{H}_{2} \mathrm{O}_{2}$ solution.

Weight of water in EHOs formulation was calculated from added $\mathrm{H}_{2} \mathrm{O}_{2}$ solution.

Wight of water in modified EHOs formulation was calculated from added $1 \mathrm{M} \mathrm{KOH}(\mathrm{pH}=8.5)$ solution and $\mathrm{H}_{2} \mathrm{O}_{2}$ solution.

In modified EHOs formulations, $\mathrm{pH}$ of $1 \mathrm{M} \mathrm{KOH}$ solution ( $\mathrm{pH} 8.5$ ) was adjusted using citric acid.

Processing time $=1 \mathrm{~h}$; agitation speed $=200$ revolutions per minute.

Sample to solvent ratio was 2-3 g cloth sample to $100 \mathrm{~mL}$ solvent. 
EHOs formulations ${ }^{\mathrm{a}}$

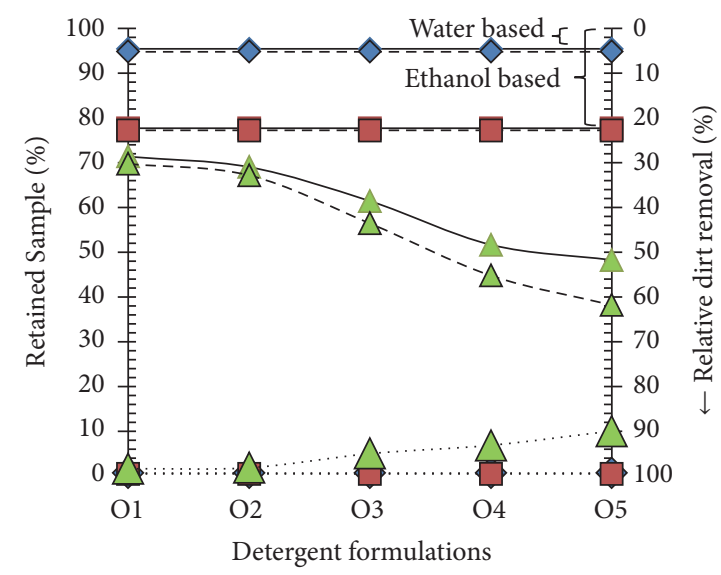

Modified EHOs formulations ${ }^{\mathrm{b}}$

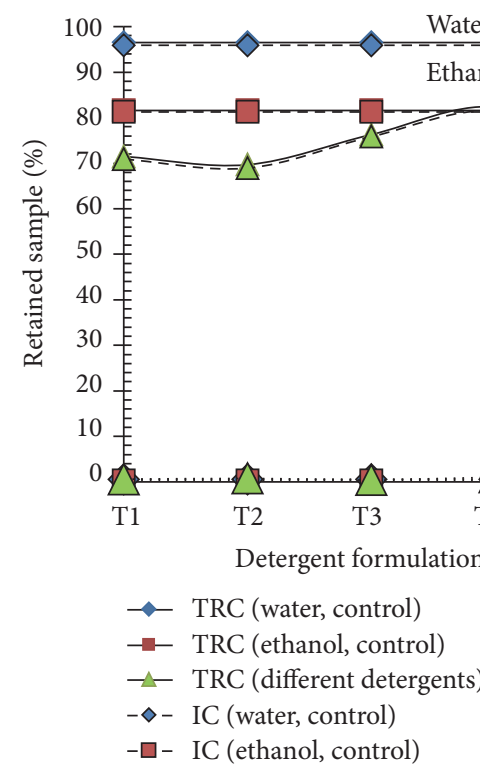

WBD formulations ${ }^{\mathrm{b}}$

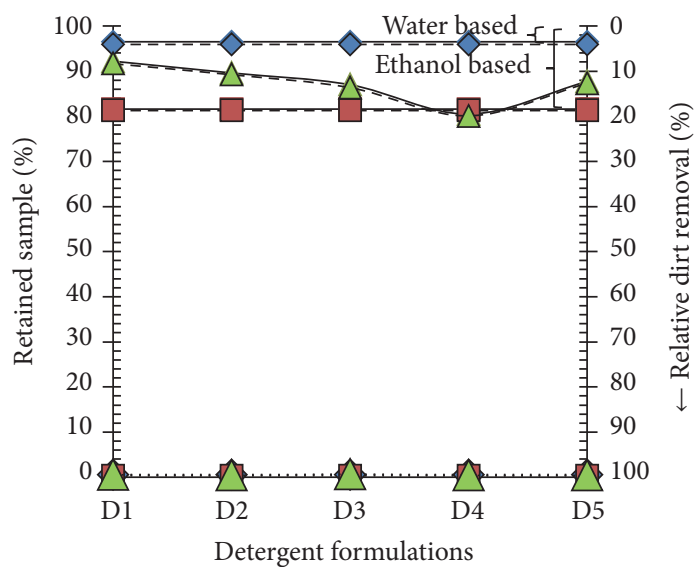

$$
\begin{aligned}
& -\Delta-\text { IC (different detergents) } \\
& . \diamond . \quad \text { RC (water, control) } \\
& \therefore \square \quad \text { RC (ethanol, control) } \\
& \therefore \Delta . \quad \text { RC (different detergents) }
\end{aligned}
$$

Figure 1: Effect of different detergent formulations on DBSCC washed samples. Note: Detergent formulations are listed in Table 2. ${ }^{a}$ Processing temperature $=60^{\circ} \mathrm{C}$; processing time $=1 \mathrm{~h}$; agitation speed $=200$ revolutions per minute. ${ }^{\mathrm{b}}$ Processing temperature $=40^{\circ} \mathrm{C}$; processing time $=$ $1 \mathrm{~h}$; agitation speed $=200$ revolutions per minute. $\mathrm{RC}$ contents of modified EHOs formulations and WBD formulations are overlapped with controls. Relative dirt removal represents the amount of dirt removed from IC and TRC samples in relation to unwashed cloth samples.

were compared with the responses. All numerical analyses and figures were drawn using Microsoft Excel software (version 2013, Windows 10).

\section{Results and Discussion}

The effects of different detergent formulations on the dirt removal of DBSCC samples were analyzed (Figure 1). Controls using ethanol and water at $40^{\circ}-60^{\circ} \mathrm{C}$ indicated that DBSCC samples contained the higher amount of hydrophobic dirt contents compared to hydrophilic dirt contents (Figure 1). Moreover, the temperature had a significant effect on the removal of hydrophobic dirt contents compared to hydrophilic dirt contents of DBSCC samples. The hydrophilic dirt contents of DBSCC samples (using water controls) were in the range of $3.5 \%$ to $4.6 \%$ (of initial sample weight) at the temperature ranges of $40^{\circ} \mathrm{C}$ to $60^{\circ} \mathrm{C}$, respectively (Figure 1). On the other hand, the hydrophobic dirt contents of DBSCC samples (using ethanol controls) were in the ranges of $18.4 \%$ (at $40^{\circ} \mathrm{C}$ ) to $22.3 \%$ (at $60^{\circ} \mathrm{C}$ ) (Figure 1 ). The change of temperature from $60^{\circ} \mathrm{C}$ to $40^{\circ} \mathrm{C}$ reduced RC content and increased IC content of the washed samples (Figure 1). All EHOs formulations had a high $\mathrm{pH}$ (13.7-14.0) compared to modified EHOs formulations (6.1-6.9) and WBD formulations (6.77.7) at the end of the processes (Figure 2). The increased concentration of builders $\left(\mathrm{KOH}\right.$ and $\left.\mathrm{H}_{2} \mathrm{O}_{2}\right)$ with the organic solvent had both quantitative (based on sample weight) and qualitative (based on visual inspection) effects on the washed fabric samples (Figures 1-5). A complete removal of the dirt along with the dye (yellowish in color) was observed with 


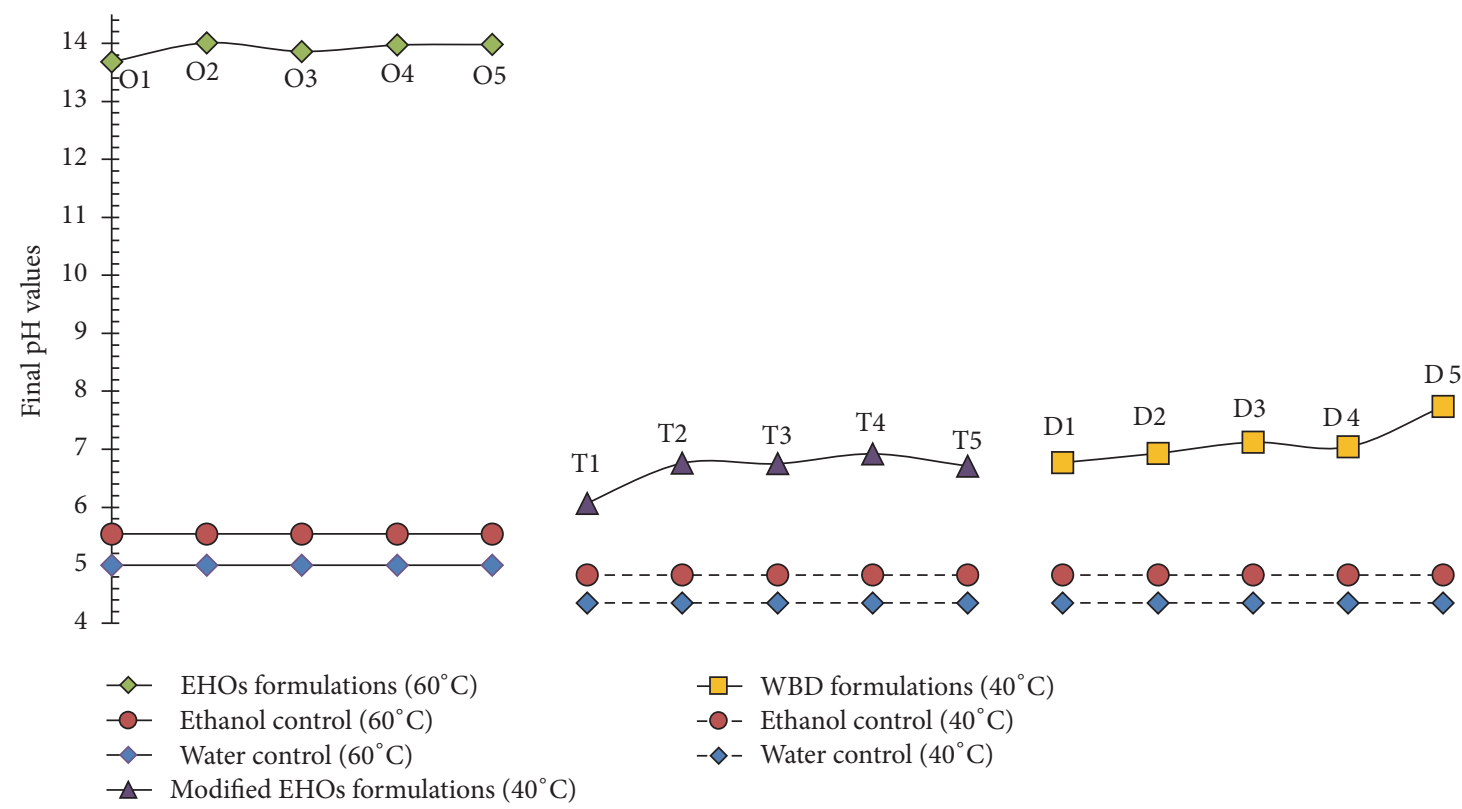

Figure 2: Final pH values of different detergent formulations at the end of the process. Note: Detergent formulations are listed in Table 2. All samples solutions were incubated for $1 \mathrm{~h}$ at 200 revolutions per minute before analysis. The final $\mathrm{pH}$ values of solutions were analyzed at room temperature $\left(25^{\circ} \mathrm{C}\right)$.

O4 and $\mathrm{O} 5$ samples using EHOs formulations (Figure 3(b)). With the application of EHOs formulations, the maximum and the minimum RC contents of $10 \%$ (of initial sample weight) and $1.6 \%$ (of initial sample weight) were observed with $\mathrm{O} 5$ and $\mathrm{O} 1$ samples, respectively (Figures 1 and 3(b)). Furthermore, O1 sample was the brightest fabric (without the dye removal) among all EHOs formulations (Figure 3(b)). The EHOs formulation at $\mathrm{O} 1$ sample also indicated the application of $758 \mathrm{~g} \mathrm{~L}^{-1}$ ethanol in the solvent formulation (Table 2, Figure 1). Both $\mathrm{pH}$ adjustment of solvent $(<8.5)$ and decrease of temperature (at $40^{\circ} \mathrm{C}$ ) had positive effects on increasing the brightness of T4 sample (modified EHOs formulation) compared to WBD formulation (Figures 1, 4-5). Moreover, RC contents of DBSCC samples resulted from modified EHOs and WBD formulations being not significantly different from O1 sample (resulting through EHOs formulation). The maximum brightness of fabric was observed with $\mathrm{T} 4$ sample (at $2.2 \mathrm{gL}^{-1} \mathrm{KOH}+45.2 \mathrm{gL}^{-1}$ $\mathrm{H}_{2} \mathrm{O}_{2}+112.1 \mathrm{~g} \mathrm{~L}^{-1}$ water $+667 \mathrm{~g} \mathrm{~L}^{-1}$ ethanol) in modified EHOs solvent formulation (Table 2, Figure 4). The change in the solvent polarity with both temperature and $\mathrm{pH}$ had the most significant effect on physical-structural properties of DBSCC samples (Table 2, Figures 1-5). However, as the digital camera captures the white balance in a field of vision, the distinction of the color (resulting through different detergent formulations) cannot be compared in the present study.

The final $\mathrm{pH}$ values of EHOs formulations (without $\mathrm{pH}$ adjustment) and the increased ones in RC of DBSCC samples indicated that the interaction between fabric and solvent would be resulting due to higher $\mathrm{pKa}$ values of $\mathrm{KOH}$ ( $\mathrm{pKa}$ value $=16$ ) compared to cellulosic hydroxyl groups $(\mathrm{pKa}$ value $=14)$ [25] of fabric samples. A pKa value represents the strength of acid solution and is directly proportional to Gibbs energy change [26]. The mixing of $\mathrm{KOH}$ with $\mathrm{H}_{2} \mathrm{O}_{2}$ increased both $\mathrm{pH}$ of the solvent [27] and the molecular dissociation of $\mathrm{H}_{2} \mathrm{O}_{2}$ ( $\mathrm{pKa}$ value 11.6) into water and molecular oxygen. The dissociation of $\mathrm{H}_{2} \mathrm{O}_{2}$ is both $\mathrm{pH}$ and temperature dependent. $\mathrm{H}_{2} \mathrm{O}_{2}$ has a half shelf life of $1 \mathrm{~h}\left(\right.$ at $\left.80^{\circ} \mathrm{C}\right)$ to $5 \mathrm{~h}\left(\right.$ at $\left.60^{\circ} \mathrm{C}\right)[28,29]$. The temperature dependency of $\mathrm{H}_{2} \mathrm{O}_{2}$ (as in modified EHOs formulations) indicated that the solvent could be utilized more than five times in the process before its recycling. The use of organic solvent such as ethanol in the fabric cleaning has several advantages over water. The lower heat of vaporization of ethanol $\left(840 \mathrm{KJ} \mathrm{Kg}^{-1}\right)$ compared to water $\left(2,260 \mathrm{KJ} \mathrm{Kg}^{-1}\right)$ reduces the high temperature requirement both during and after the process (such as recycling of solvent stream). Different physiochemical properties of ethanol (such as polarity, thermal conductivity, viscosity, and surface tension) compared to water has an important role in organic solvent based detergent formulations. The lower polarity of ethanol $\left(\right.$ dipole moment $=5.64 \times 10^{-30} \mathrm{C} \mathrm{m}$, dielectric constant $=$ 25.3 at $20^{\circ} \mathrm{C}$, as in EHOs formulations) compared to water $\left(\right.$ dipole moment $=6.19 \times 10^{-30} \mathrm{C} \mathrm{m}$, dielectric constant $=80.1$ at $20^{\circ} \mathrm{C}$, as in WBD formulations) would lead to the removal of hydrophobic dirt contents of DBSCC samples [23]. The lower polarity of ethanol also stabilizes $\mathrm{H}_{2} \mathrm{O}_{2}$ (dipole moment $=5.25 \times 10^{-30} \mathrm{C} \mathrm{m}$, dielectric constant $=74.6$ at $\left.17^{\circ} \mathrm{C}\right)[23]$ compared to water alone $[29,30]$. In addition, alkaline $\mathrm{pH}$ maintains the stability of ethanol molecules compared to acidic $\mathrm{pH}$ condition $[31,32]$. In the alkaline $\mathrm{pH}$, ethanol acts as a proton donor and denatures upon deprotonation (inconsumable in nature at high $\mathrm{pH}$ ). The deprotonated ethanol would stabilize by noncovalent bonding of potassium ion (from $\mathrm{KOH}$ ) or sodium ion (from $\mathrm{NaOH}$ ) and would result in the formation of potassium ethoxide or sodium 
A. Before processing

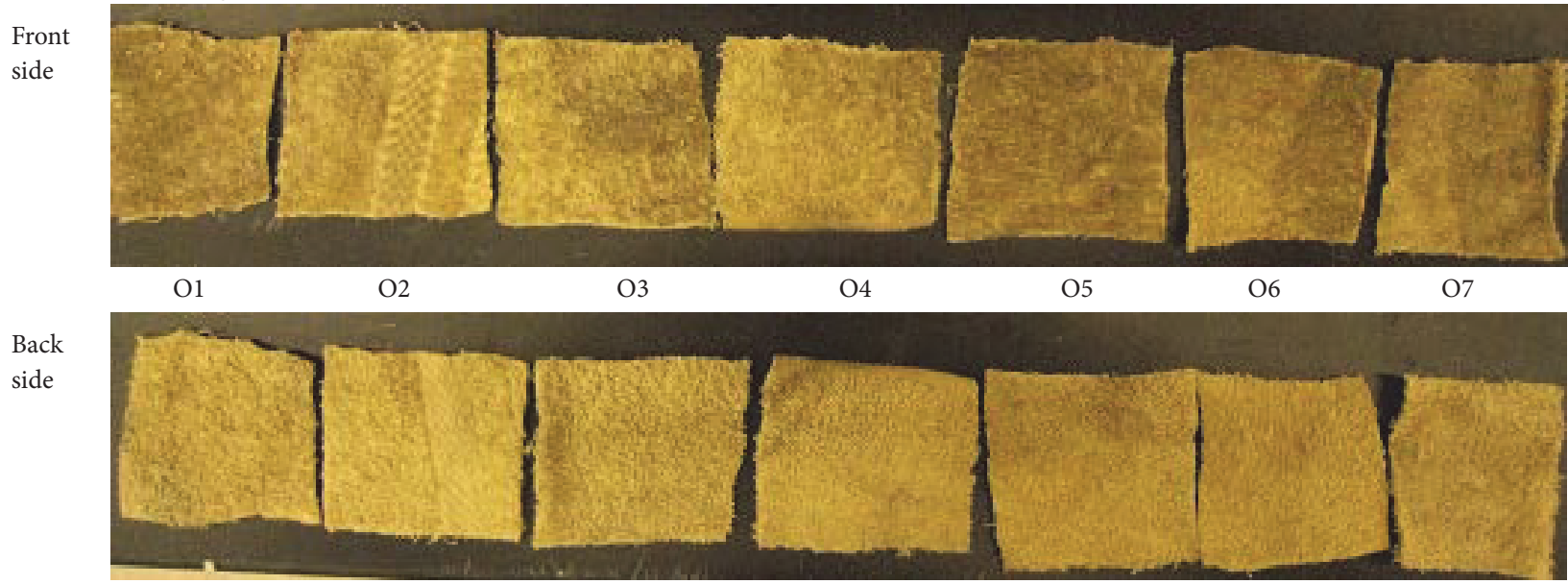

B. Before incubation

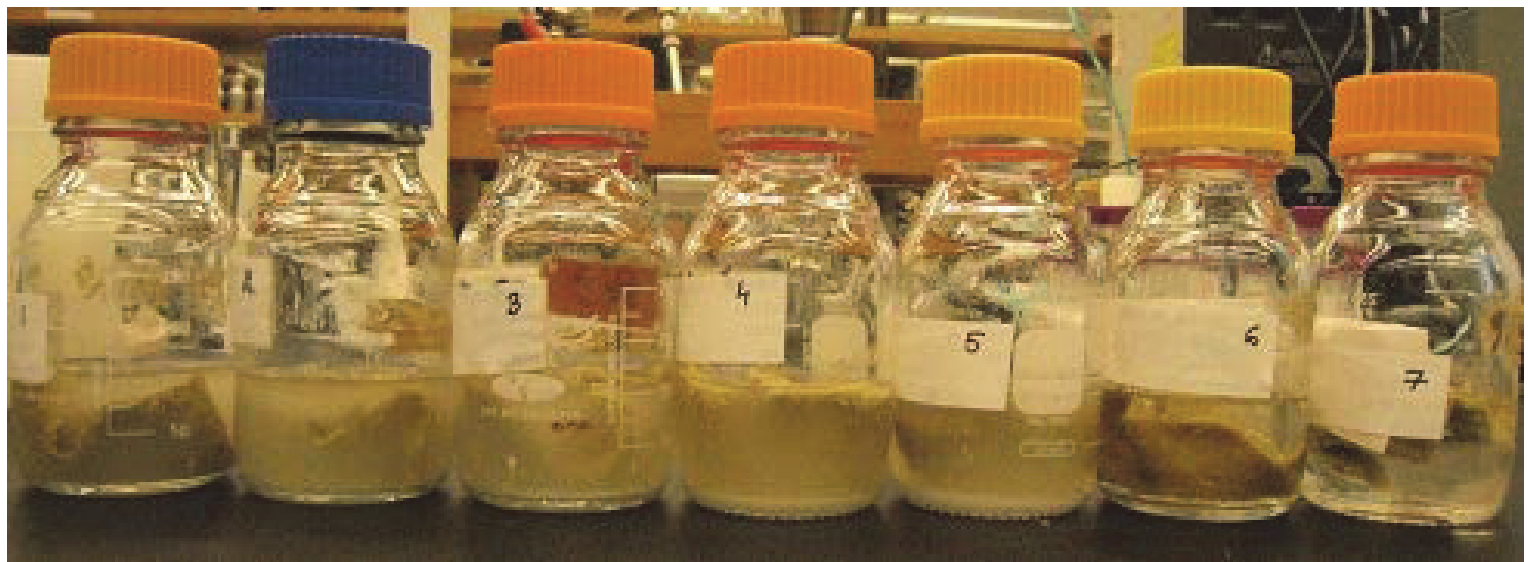

C. After time incubation

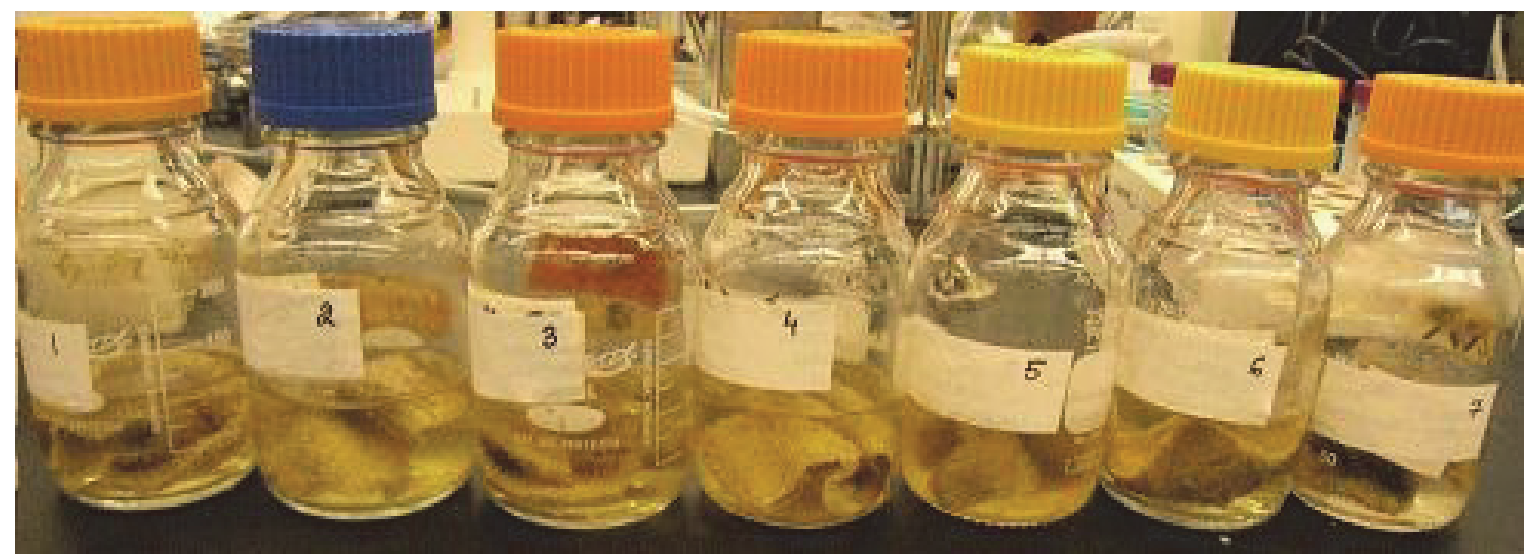

\section{After drying}

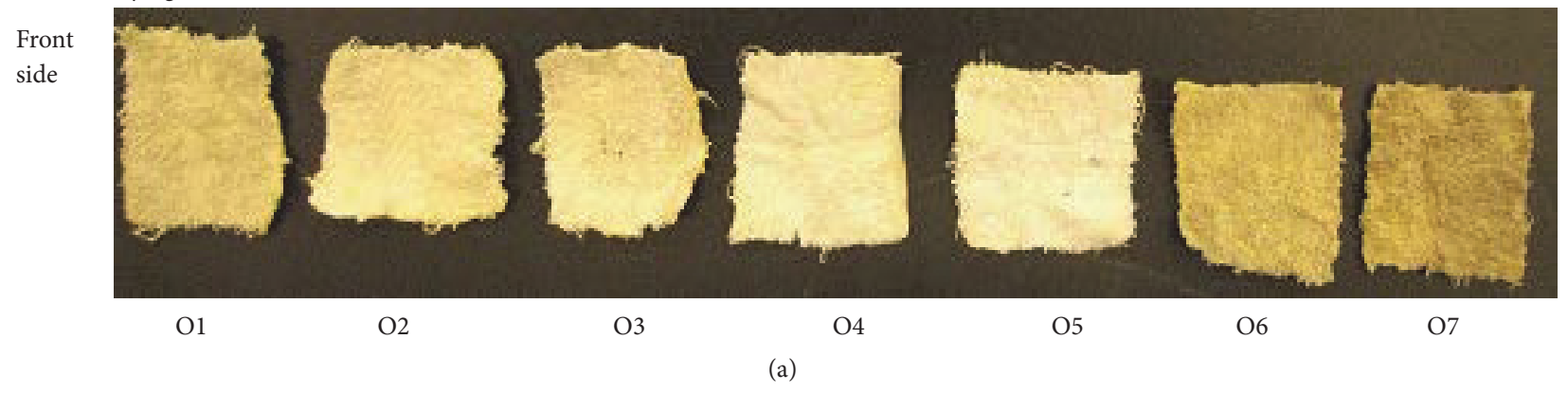

Figure 3: Continued. 


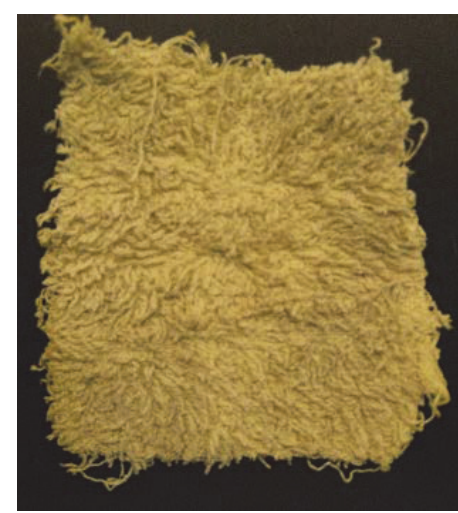

O1

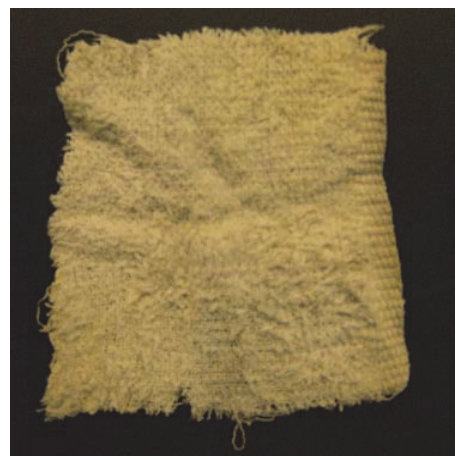

O4

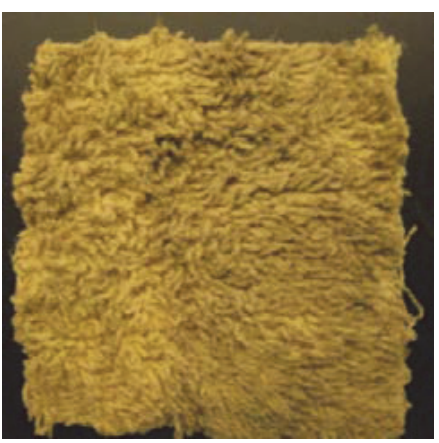

O7 (control)

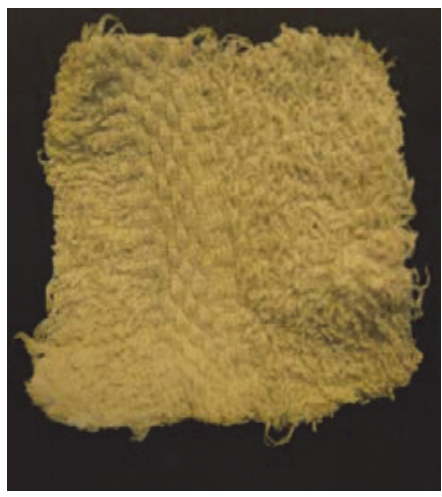

$\mathrm{O} 2$

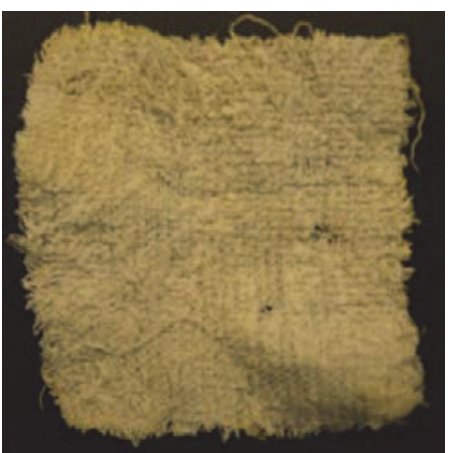

O5

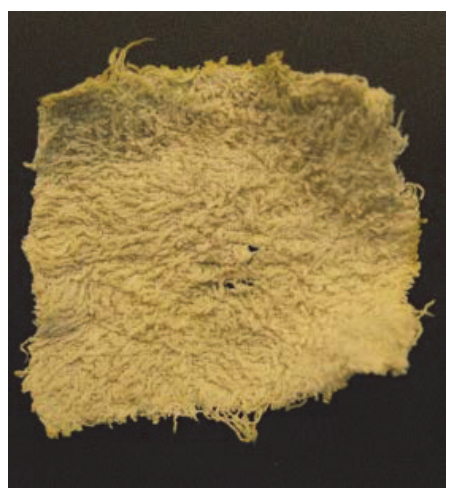

O3

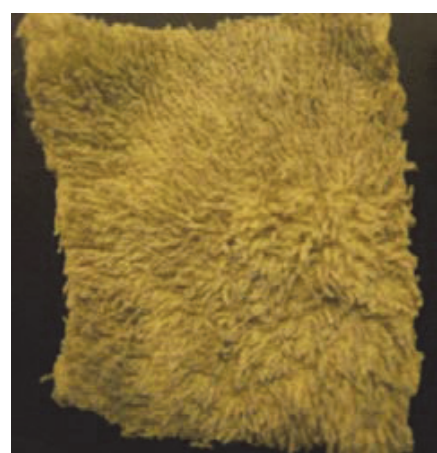

O6 (control)

(b)

FIGURE 3: (a) Images of DBSCC samples to demonstrate the effects of EHOs formulations (without pH adjustment) on brightness of cloth fabric. Note: An alphabetical integer value represents composition of detergent formulation as listed in Table 2. (b) Closed visual images of dried cloth samples resulted from EHOs formulations (without $\mathrm{pH}$ adjustment). Note: A positive integer value represents compositions of different detergent formulation as listed in Table 2.

ethoxide. Both potassium ethoxide and sodium ethoxide are highly corrosive and nucleophilic in nature [22]. The noncovalent interaction of potassium ion with deprotonated ethanol remains much stronger compared to sodium ion due to their different $\mathrm{pKa}$ values. Both potassium ethoxide and sodium ethoxide, known as alkoxides, are soluble in ethanol and have high reactivity with water [23]. The high reactivity of alkoxides (diluted in ethanol, as in EHOs detergent formulations without $\mathrm{pH}$ adjustment) with water solvent also facilitates $\mathrm{pH}$ neutralization (using hydrochloric acid or citric acid) of EHOs solvent (after $\mathrm{H}_{2} \mathrm{O}_{2}$ dissociation) followed by distillation process, to regain ethanol in its physiochemical form as shown in Table 1. The ethanol recovery of $99.2 \%$ has been reported at the end of the EHOs process [21]. The use of $\mathrm{NaOH}$ in $\mathrm{EHOs}$ detergent formulations would provide better economical outcome compared to $\mathrm{KOH}$ utilization in the process. The lower $\mathrm{pKa}$ value of $\mathrm{NaOH}$ compared to $\mathrm{KOH}$ would result in the production of minimum $\mathrm{RC}$ and is subjected to further research.

In EHOs formulations (both with and without $\mathrm{pH}$ controlled), the interaction of DBSCC samples with the solvent occurs through the formation of ethoxide ion and hydroxide 


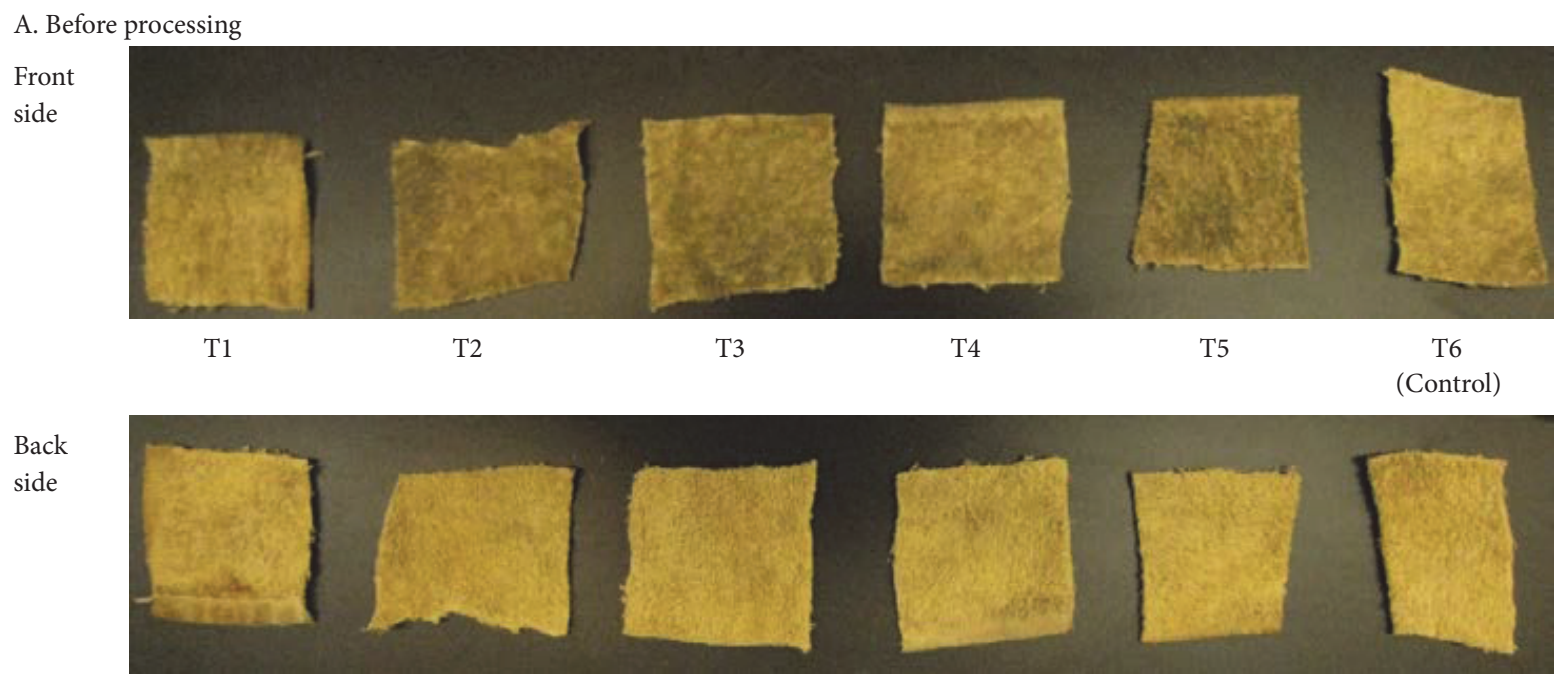

B. After time incubation

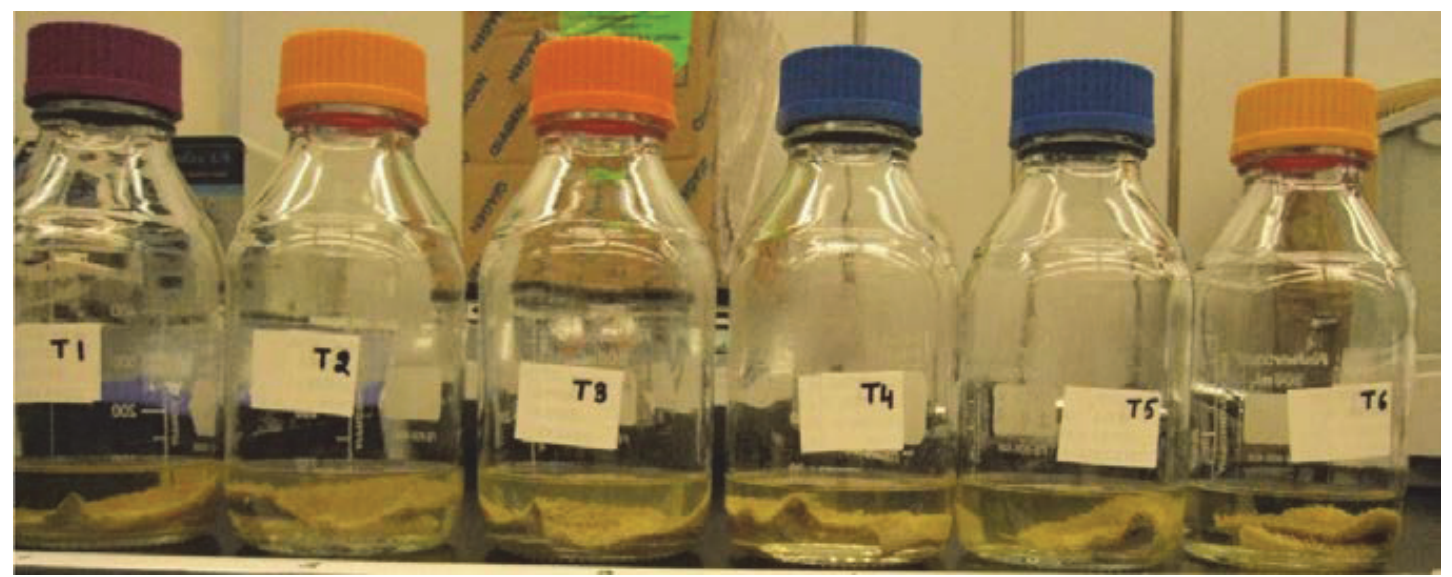

C. After drying

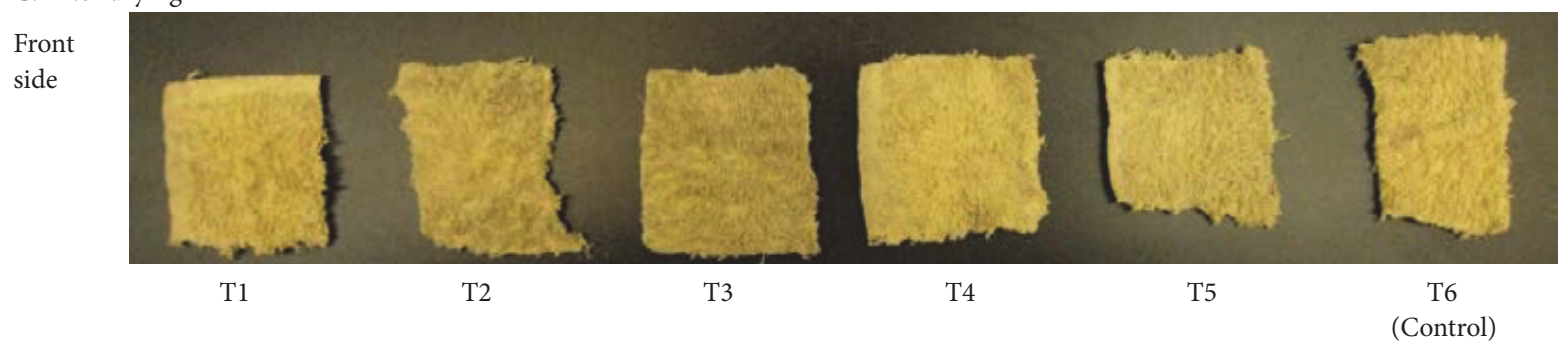

FIgURE 4: Visual views of cloth samples processed with modified EHOs formulations (with pH adjustment). Note: An alphabetical integer value represents compositions of different detergent formulation as listed in Table 2.

ion. The movement of ionic species (hydroxyl and ethoxide ions) is governed through the conductivity of a solvent. The thermal conductivities of pure water and pure ethanol differ from $0.61 \mathrm{~W} \mathrm{~m}^{-1} \mathrm{~K}^{-1}$ (at $25^{\circ} \mathrm{C}, 1$ bar) to $0.65 \mathrm{~W} \mathrm{~m}^{-1} \mathrm{~K}^{-1}$ (at $62.5^{\circ} \mathrm{C}, 1$ bar) and $0.17 \mathrm{~W} \mathrm{~m}^{-1} \mathrm{~K}^{-1}$ (at $25^{\circ} \mathrm{C}, 1$ bar) to $0.16 \mathrm{~W} \mathrm{~m}^{-1} \mathrm{~K}^{-1}$ (at $62.5^{\circ} \mathrm{C}, 1$ bar), respectively [23]. The lower thermal conductivity of ethanol solvent (as in EHOs formulations) also indicated that the temperature dependence of ionic species mobility would be smaller compared to water solvent (as in WBD formulations). Both viscosity and surface tension of the solvent have a role in transportation and interaction of ionic species with the inner matrix of
DBSCC samples. The viscosities of pure water and pure ethanol differ from $0.89 \mathrm{mPas}$ (at $25^{\circ} \mathrm{C}$ ) to $0.46 \mathrm{mPa}$ (at $62.5^{\circ} \mathrm{C}$ ) and $1.07 \mathrm{mPas}$ (at $25^{\circ} \mathrm{C}$ ) to $0.58 \mathrm{mPas}$ (at $62.5^{\circ} \mathrm{C}$ ), respectively [23], whereas the surface tensions of pure water and pure ethanol differ from 72.75 (at $20^{\circ} \mathrm{C}$ ) to $66.24 \mathrm{mN} \mathrm{m}^{-1}$ (at $60^{\circ} \mathrm{C}$ ) and $22.39 \mathrm{mN} \mathrm{m}^{-1}$ (at $20^{\circ} \mathrm{C}$ ) to $19.06 \mathrm{mN} \mathrm{m}^{-1}$ (at $60^{\circ} \mathrm{C}$ ), respectively $[23,33]$. The reduction in the surface tension would be correlated to decrease in hydrogen bonding capability of ethanol. The reduced surface tension of organic solvent and the increased pressure would enhance the wetting power of fabric $[10,20,21]$. Jain and coresearchers [20, 21] have reported that the addition of at least $450 \mathrm{~g} \mathrm{~L}^{-1}$ of ethanol 
A. Before processing

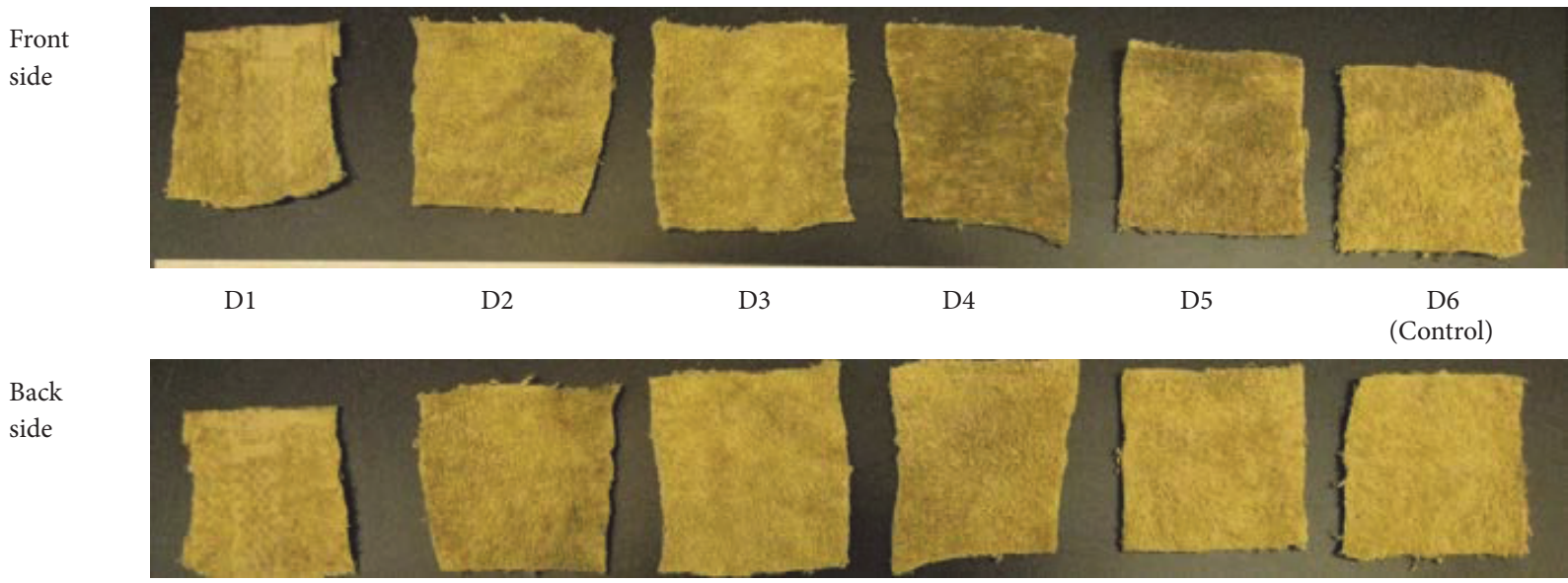

B. After time incubation

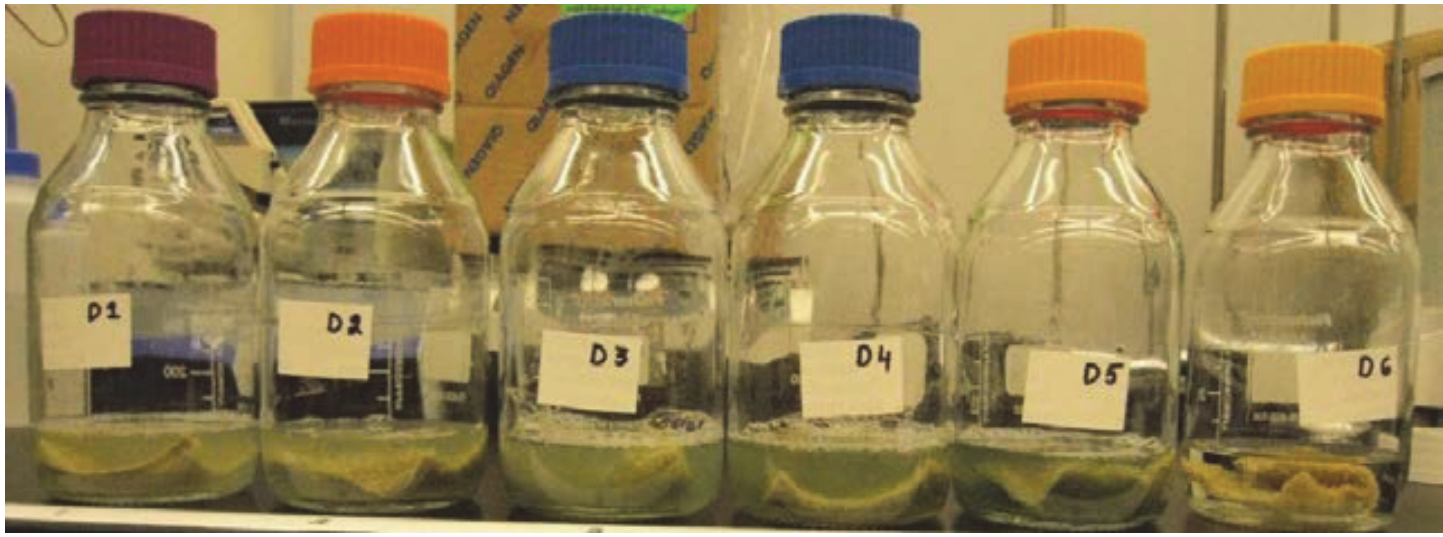

C. After drying

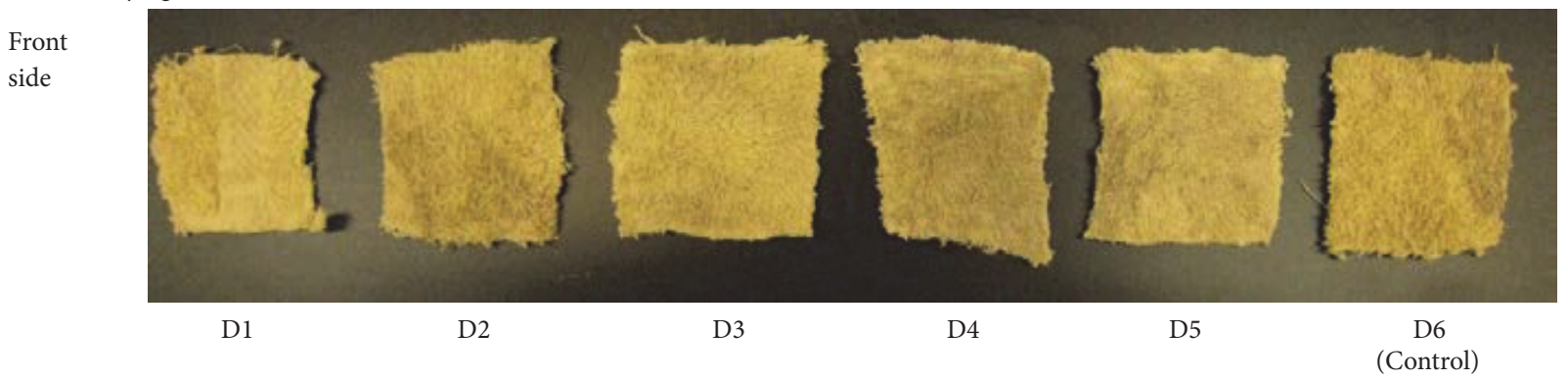

FIGURE 5: Visual views of cloth samples processed with WBD formulations (commercial detergent T). Note: An alphabetical integer value represents compositions of different detergent formulation as listed in Table 2.

concentration in EHOs solvent formulations would remove the foaming phenomenon resulting from an exothermic reaction of $\mathrm{KOH}$ and $\mathrm{H}_{2} \mathrm{O}_{2}[20,21]$. The generated pressure in EHOs solvent formulations is dependent on several different factors including ethanol concentration, $\mathrm{KOH}$ concentration, $\mathrm{H}_{2} \mathrm{O}_{2}$ concentration, and the total vessel loading [20, 21]. At approximate $87 \%$ reactor vessel loading (comprised of $300 \mathrm{~g}$ sugarcane bagasse with $3 \mathrm{~L}$ of EHOs solvent (consisting of $25 \mathrm{~g} \mathrm{~L}^{-1} \mathrm{KOH}, 25 \mathrm{~g} \mathrm{~L}^{-1} \mathrm{H}_{2} \mathrm{O}_{2}, 250 \mathrm{~g} \mathrm{~L}^{-1}$ water, and $525 \mathrm{~g} \mathrm{~L}^{-1}$ ethanol)) the temperature of the vessel was raised from $37^{\circ} \mathrm{C}$ to $67^{\circ} \mathrm{C}$ corresponding to 27.58 bar of pressure within 10 minutes after the addition of $\mathrm{H}_{2} \mathrm{O}_{2}$ [20], whereas at approximate 58\% reactor vessel loading (comprised of $200 \mathrm{~g}$ pinewood chips with $2 \mathrm{~L}$ of EHOs solvent (consisting of $50 \mathrm{~g} \mathrm{~L}^{-1} \mathrm{KOH}, 50 \mathrm{~g} \mathrm{~L}^{-1} \mathrm{H}_{2} \mathrm{O}_{2}, 237 \mathrm{~g} \mathrm{~L}^{-1}$ water, and $450 \mathrm{~g} \mathrm{~L}^{-1}$ ethanol)), the generated pressure of 11 bar to 15.2 bar was observed at $60^{\circ}$ to $80^{\circ} \mathrm{C}$, respectively, after 5 minutes (the point at which pressure started building up) to 20 minutes (the point at which the static pressure was observed) after the addition of $\mathrm{H}_{2} \mathrm{O}_{2}$ [21]. In both cases (at $87 \%$ and $58 \%$ reactor vessel loadings), the pressure and temperature rose slowly and gradually [20, 21]. A pressure range of 4.4-5.6 bar (to increase a tensile strength of cotton fabric) [34] and temperature range of $30^{\circ}-110^{\circ} \mathrm{C}[4,5]$ have been reported 


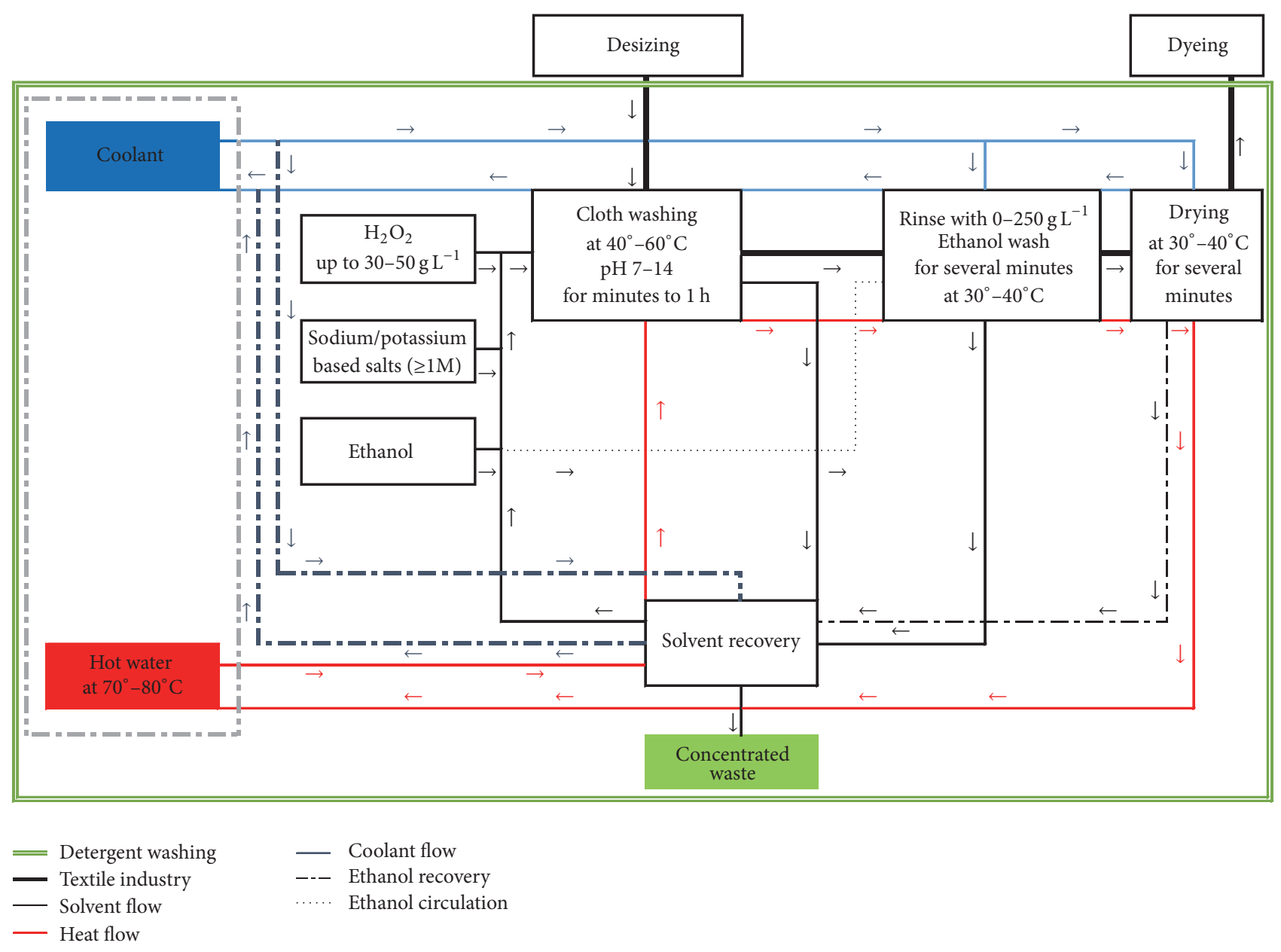

Figure 6: Process flow diagram to demonstrate the utilization of EHOs solvent in textile and detergent processes.

in textile processing. Both the absence of foaming and rise in temperature of the vessel would increase the safety of the process during the scale-up (with the controlling and adjustment of a generated pressure in the vessel based on the process requirement) and would eliminate the external power source in the process, respectively.

The usage of large quantities of organic solvent (flammable in nature) and generation of pressure in EHOs formulations (with and without modification) also indicated its applicability at industry (such as textile) and large intuitions (such as hospitals, and hotels) compared to common household usage (Figure 6). In textile industry, the application of EHOs formulations at $60^{\circ}-70^{\circ} \mathrm{C}$ (under pressurized condition) would be useful in the development of scouring, bleaching, and mercerization unit operations as a single unit operation. Moreover, the same process (EHOs formulations) would be utilized in the recycling of used fabric (either through bleaching or through dirt removal without affecting color). The use of ethanol in the process also provides its applicability in energy or heat generation through anaerobic sludge system [35] that would be an excellent source of energy production in textile industry in remote areas [20]. The implication of the suggested process in textile industry would minimize water usage by at least 38\% compared to the current process [3]. Moreover, both EHOs and modified EHOs formulations would be ideal in the development of medical textile accessories [1]. These organic solvent based formulations (both EHOs and modified EHOs) would be useful in controlling and maintaining a hygienic environment in water-limited regions of the world such as Middle East, Australia, India (such as Rajasthan), and USA (such as California, Nevada). Furthermore, ethanol concentration of $552 \mathrm{~g} \mathrm{~L}^{-1}$ in the solvent formulation (as in modified EHOs formulation) precipitates potassium citrate as salt with $\mathrm{pH}$ of 6.5-8.0 [36]. However, the precipitated salt would be either recycled in the EHOs solvent formulation or collected for another application such as kidney stone removal [37]. The present study provided insight for the utilization of used fabric for its recycling and cleaning using both EHOs and modified EHOs formulations. Further research is required with organic solvent based detergent optimization based on processing temperature, ethanol concentration, potassium citrate or sodium citrate solutions strength, $\mathrm{pH}$, hydrogen peroxide concentration, and processing time as variables. All these variables would be optimized using six variables' response surface methodology. The measurement of tensile 
strength [38] and reflectance (K/S value) [39] of fabric along with visual/microscopic analyses would be useful in determination of qualitative and quantitative effects of EHOs detergent formulations. The fact that ethanol, $\mathrm{KOH} / \mathrm{NaOH}$, citric acid, and $\mathrm{H}_{2} \mathrm{O}_{2}$ are sustainable compounds and the optimal utilization and integration of the solvent stream make EHOs detergent formulation environmentally beneficial and interesting for the large scale applications.

\section{Conclusions}

Utilization of EHOs formulations in fabric cleaning provides flexibility with both $\mathrm{pH}$ and processing temperature. The development of EHOs formulations based textile and detergent processes at commercial scale would be beneficial in the elimination of the environmental pollutants resulting through the discharge of generated waste products in water stream. Moreover, the organic solvent based EHOs formulation would be beneficial in self-sustainable industry development in water-limited regions.

\section{Abbreviations}

EHOs: Ethyl-hydro-oxides

WBD: Water based detergent

DBSCC: Dried biodiesel soaked cotton cloth.

\section{Competing Interests}

The author declares that he has no competing interests.

\section{Authors' Contributions}

Author Arpan Jain conceptualized the research work and worked on the manuscript.

\section{References}

[1] A. J. Rigby, S. C. Anand, and A. R. Horrocks, "Textile materials for medical and healthcare applications," Journal of the Textile Institute, vol. 88, no. 1, pp. 83-93, 1997.

[2] J. J. Porter, D. W. Lyons, and W. F. Nolan, "Water uses and wastes in the textile industry," Environmental Science and Technology, vol. 6, no. 1, pp. 36-41, 1972.

[3] M. A. Shaikh, "Water conservation in textile industry," Pakistan Textile Journal, vol. 58, no. 11, pp. 48-51, 2009.

[4] R. Sundara, "Temperature control is vital to maximization of the peroxide bleaching process," Can Chem News, vol. 50, no. 1, pp. $15-17,1998$

[5] S. B. Abdul and G. Narendra, "Accelerated bleaching of cotton material with hydrogen peroxide," Journal of Textile Science \& Engineering, vol. 3, no. 4, article 4, 2013.

[6] T. Wagaw and R. B. Chavan, "Optimization of caustic soda concentration for causticization of cotton," Open Access Scientific Reports, vol. 1, no. 9, p. 6, 2012.

[7] Y. Yue, G. Han, and Q. Wu, "Transitional properties of cotton fibers from cellulose I to cellulose II structure," BioResources, vol. 8, no. 4, pp. 6460-6471, 2012.
[8] B. R. Babu, A. K. Parande, S. Raghu, and T. P. Kumar, "Cotton textile processing: waste generation and effluent treatment," Journal of Cotton Science, vol. 11, no. 3, pp. 141-153, 2007.

[9] A. R. Tehrani-Bagha and K. Holmberg, "Solubilization of hydrophobic dyes in surfactant solutions," Materials, vol. 6, no. 2, pp. 580-608, 2013.

[10] E. Smulders, Ed., Laundry Detergents, John Wiley \& Sons, Weinheim, Germany, 2002.

[11] O. Kirk, T. V. Borchert, and C. C. Fuglsang, "Industrial enzyme applications," Current Opinion in Biotechnology, vol. 13, no. 4, pp. 345-351, 2002.

[12] R. M. Banik and M. Prakash, "Laundry detergent compatibility of the alkaline protease from Bacillus cereus," Microbiological Research, vol. 159, no. 2, pp. 135-140, 2004.

[13] E. E. Whitley, "Fungicidal detergent composition," US Patent 4164477 A, 1979.

[14] M. Vanhanen, T. Tuomi, U. Tiikkainen, O. Tupasela, R. Voutilainen, and H. Nordman, "Risk of enzyme allergy in the detergent industry," Occupational \& Environmental Medicine, vol. 57, no. 2, pp. 121-125, 2000.

[15] K. Sarlo, "Control of occupational asthma and allergy in the detergent industry," Annals of Allergy, Asthma and Immunology, vol. 90, no. 5, pp. 32-34, 2003.

[16] N. Ross, "World water quality facts and statistics," Water World Day 2010, Pacific Institute 2010.

[17] B. J. Green and D. H. Beezhold, "Industrial fungal enzymes: an occupational allergen perspective," Journal of Allergy, vol. 2011, Article ID 682574, 11 pages, 2011.

[18] I. Kowalska, M. Kabsch-Korbutowicz, K. Majewska-Nowak, and M. Pietraszek, "Removal of detergents from industrial wastewater in ultrafiltration process," Environment Protection Engineering, vol. 31, no. 3-4, pp. 207-219, 2005.

[19] P. Pandey and B. Gopal, "Detergents on the growth of two plants: Azolla pinnata and Hydrilla verticillata," Environment of We: An International Journal of Science \& Technology, vol. 5, pp. 107-114, 2010.

[20] A. Jain, Y. Wei, and A. Tietje, "Biochemical conversion of sugarcane bagasse into bioproducts," Biomass and Bioenergy, vol. 93, pp. 227-242, 2016.

[21] A. Jain and W. C. Bridges, "Comparison of chemical treatment methods for loblolly pine to utilize as enzyme hydrolyzate feedstock," Biomass and Bioenergy, vol. 94, pp. 130-145, 2016.

[22] National Center for Biotechnology Information, PubChem Compound Database, https://pubchem.ncbi.nlm.nih.gov.

[23] D. R. Lide, Ed., CRC Handbook of Chemistry and Physics, CRC Press, Boca Raton, Fla, USA, 2005.

[24] A. Albert and E. P. Serjeant, The Determination of Ionization Constants-a Laboratory Manual, Chapman and Hall, New York, NY, USA, 3rd edition, 1984.

[25] M. T. Goulet, The effect of pulping, bleaching, and refining operations on the electrokinetic properties of wood fiber fines [Ph.D. thesis], Lawrence University, Atlanta, Ga, USA, 1989.

[26] J. Reijenga, A. van Hoof, A. van Loon, and B. Teunissen, "Development of methods for the determination of pKa values," Analytical Chemistry Insights, vol. 8, no. 1, pp. 53-71, 2013.

[27] A. Jain and T. H. Walker, "Pretreatment composition for biomass conversion process," US patent application WO 2013151927 A1, 2013.

[28] A. Karlsson and R. Agnemo, "High consistency hydrogen peroxide bleaching of mechanical pulps with varying amounts 
of fines," Nordic Pulp and Paper Research Journal, vol. 25, no. 3, pp. 256-268, 2010.

[29] H. U. Suess, D. GmbH, M. Janik, and A. Q. GmbH, "On the decomposition of hydrogen peroxide via the peroxocarbonic acid anion," TAPPSA, http://www.tappsa.co.za/archive3/papers/ decomposition_of_hydrogen_pero/decomposition_of_hydrogen_ pero.html.

[30] M. A. G. Mitchell and W. F. K. Wynne-Jones, "Thermodynamic and other properties of solutions involving hydrogen bonding," Discussions of the Faraday Society, vol. 15, pp. 161-168, 1953.

[31] E. E. Fileti, P. Chaudhuri, and S. Canuto, "Relative strength of hydrogen bond interaction in alcohol-water complexes," Chemical Physics Letters, vol. 400, no. 4-6, pp. 494-499, 2004.

[32] J. A. Saiz, E. Padro, and L. Guaardia, "Dynamics and hydrogen bonding in liquid ethanol," Molecular Physics, vol. 97, no. 7, pp. 897-905, 1999.

[33] H. Ghahremani, A. Moradi, J. Abedini-Torghabeh, and S. M. Hassani, "Measuring surface tension of binary mixtures of water + alcohols from the diffraction pattern of surface ripples," Der Chemica Sinica, vol. 2, no. 6, pp. 212-221, 2011.

[34] M. Akhbari, A. Zahiri, and S. J. E. Bassam, "Optimization of parameters influencing mercerization using the RSM method in order to increase the tensile strength of mercerized yarn," Fibres and Textiles in Eastern Europe, vol. 94, no. 5, pp. 30-35, 2012.

[35] M. Ghorbanian, Enhancement of anaerobic digestion of actual industrial wastewaters: reactor stability and kinetic modeling [Ph.D. thesis], University of Louisville, Louisville, KY, USA, 2014.

[36] A. Alon and P. W. Staal, "Methods for the preparation and recovery of alkali metal citrates," US Patent 5041645, 1991.

[37] H. Xu, A. L. Zisman, F. L. Coe, and E. M. Worcester, "Kidney stones: an update on current pharmacological management and future directions," Expert Opinion on Pharmacotherapy, vol. 14, no. 4, pp. 435-447, 2013.

[38] K. El-Badry, S. M. Salah, and S. O. Bahlool, "Effect of mercerization techniques on cotton towels properties," Journal of Applied Sciences Research, vol. 9, no. 2, p. 8, 2013.

[39] A. K. Samanta, S. Mitra, D. Singhee, and S. Parekh, "Efficacy of selective surfactants/detergents as washing agents on soiled white and dyed cotton fabrics," Indian Journal of Fibre and Textile Research, vol. 29, no. 2, pp. 223-232, 2004. 

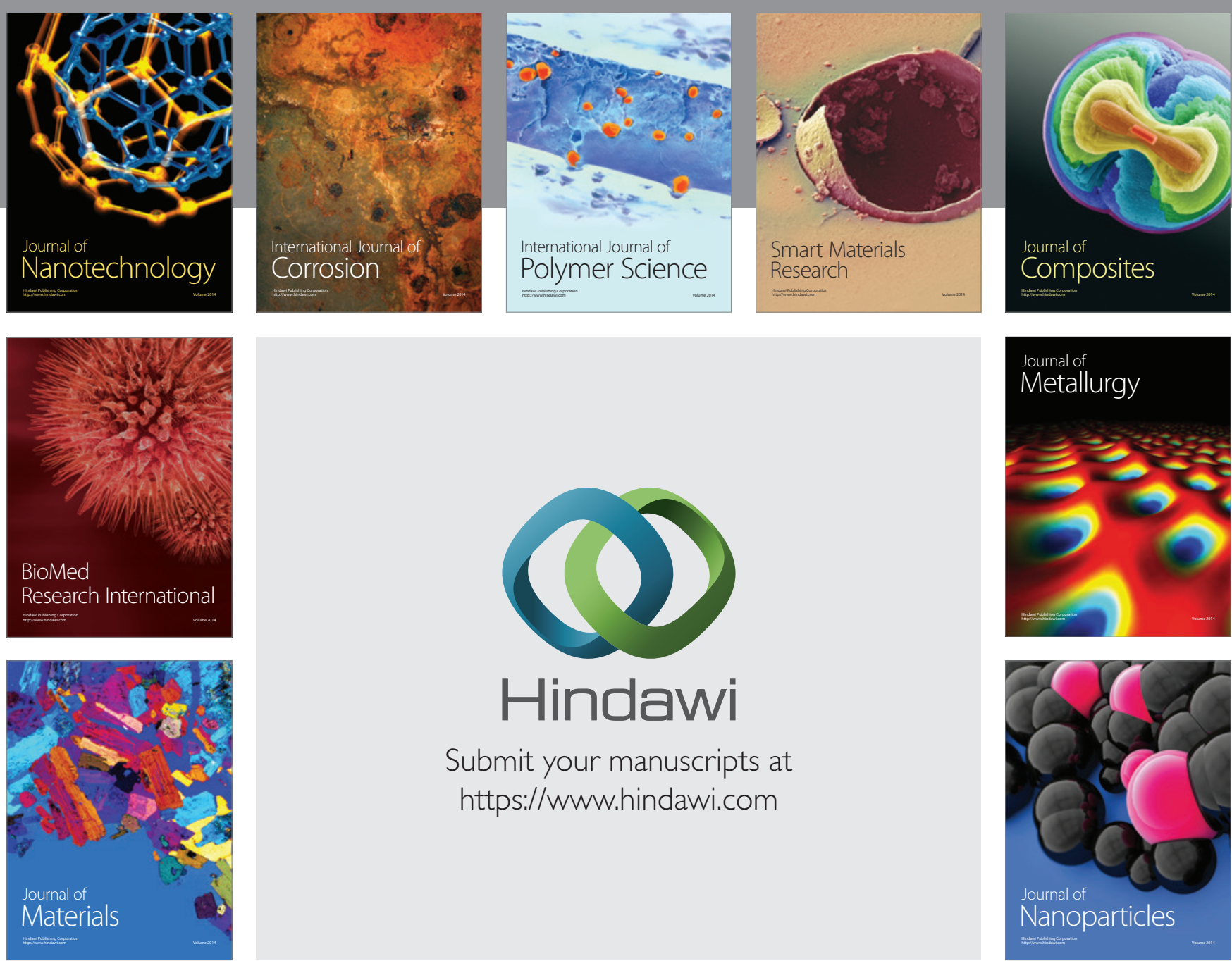

\section{Hindawi}

Submit your manuscripts at

https://www.hindawi.com

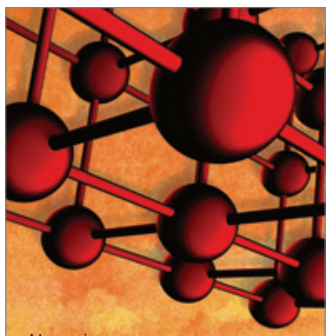

Materials Science and Engineering
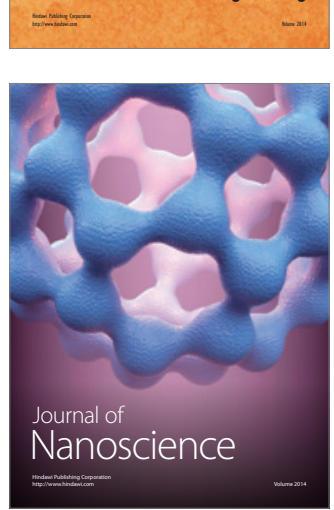
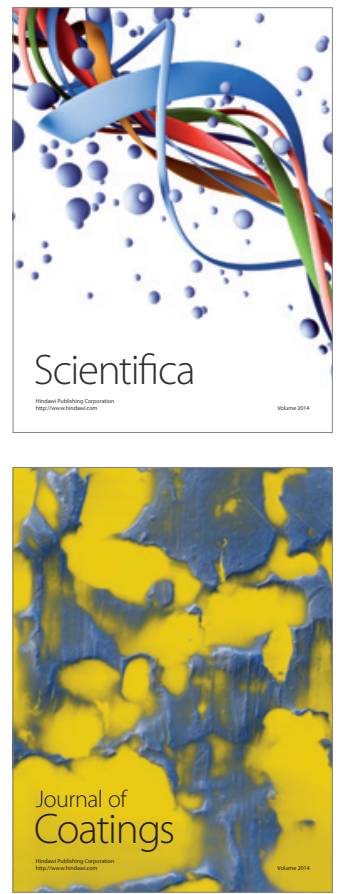
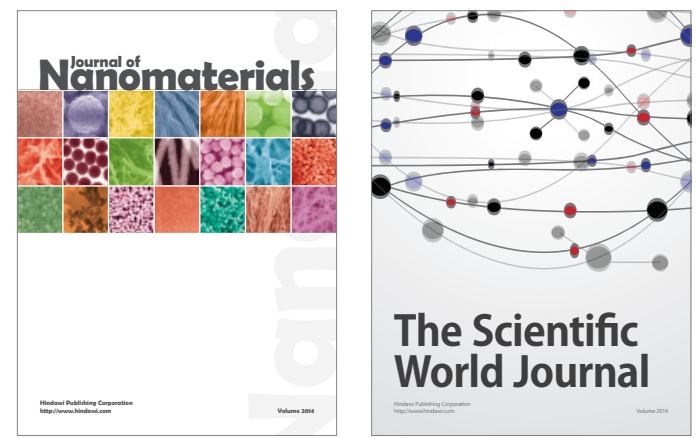

The Scientific World Journal
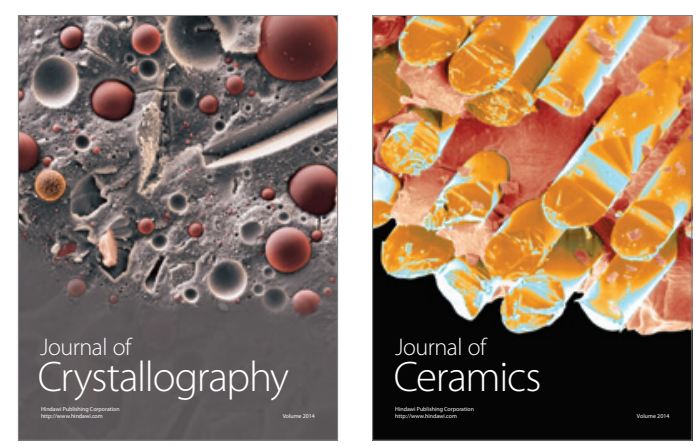
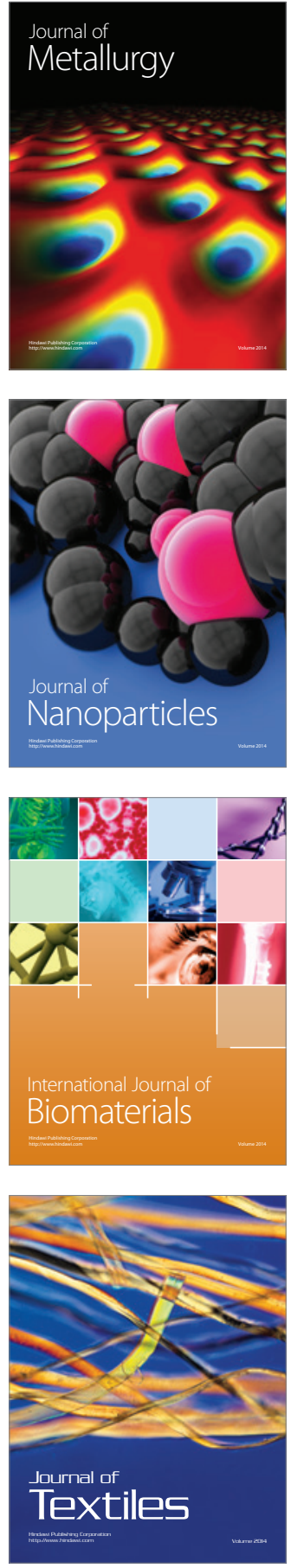